10-1-1996

\title{
Legislation of the Value of Pi: A postscript
}

Robert J. Whitaker

Missouri State University

Follow this and additional works at: https://bearworks.missouristate.edu/articles-cnas

\section{Recommended Citation}

Whitaker, Robert J. "Legislation of the value of Pi: A postscript." The Physics Teacher 34, no. 7 (1996): 410-410.

This article or document was made available through BearWorks, the institutional repository of Missouri State University. The work contained in it may be protected by copyright and require permission of the copyright holder for reuse or redistribution.

For more information, please contact BearWorks@library.missouristate.edu. 


\title{
Legislation of the Value of $\mathcal{P}_{i} \mathcal{A}$ Postscript
}

\author{
Robert J. Whitaker \\ Department of Physics and Astronomy, Southwest Missouri State University, \\ Springfield, MO 65804
}

$\mathcal{W}$ hen I surveyed the literature for my article on the legislation of $\pi,{ }^{1} \mathrm{I}$ believed that I had found all of the pertinent references, but now I must supplement what I wrote and acknowledge other contributions to this story.

An extensive account of Indiana House Bill No. 246 has been given by Arthur E. Hallerberg of Valparaiso University. ${ }^{2}$ Hallerberg also provides an extensive biography of Dr. E. J. Goodwin, Goodwin's promotion of his mathematical "discovery," and a more comprehensive account of the Bill's history, based on contemporary records in local and national newspapers, than has been published elsewhere. While several of the local newspapers in 1897 commented on the pending legislation, the only one that apparently criticized it from the beginning was the German language, Der Tägliche Telegraph. ${ }^{3} \mathrm{Hal}-$ lerberg notes:

There is little reason to suppose that many of the state legislators read the German Telegraph! As an indication of the attitude of at least some of the legislators over against foreign languages, witness another bill introduced into the same 1897 Legislature (but also not passed into law)-a bill which would have forbidden the printing of restaurant menus in French! ${ }^{4}$

Publication of Goodwin's ideas in the American Mathematical Monthly was used as argument for their validity before the Indiana legislature. Hallerberg notes, however, that during its early years the joumal printed nearly everything that was submitted to it without screening by its editors. ${ }^{5}$

Hallerberg published a second paper in 1977 , in which he briefly summarized his first paper and attempted to show what value of $\pi$ would result from Goodwin's theorem. ${ }^{6}$ Those who have attempted this problem will not be surprised to find that several possible, and different, values emerge.

In 1985 David Singmaster published another survey of the attempt to legislate the value of $\pi .^{7}$ Using those references previously cited, as well as Hallerberg's research, Singmaster made further analysis of the values of $\pi$ that are implicit in Goodwin's writings. Proceeding line by line through the wording of the House Bill and Good win's earlier note in the American Mathematical Monthly, Singmaster observes that there appear to be nine different values of $\pi$, ranging from 2.56 to 4. He notes, "...it is even possible to obtain different results from the same assertions. I am sure that some of the other analyses may have alternative values for $\pi$."8

Perhaps this discussion provides a moral and another addition to Murphy's Law: (1) No matter how complete and extensive a bibliographic resource may be (even if computerized), it will noi include everything; and, a corollary: (2) even if it does contain everything, the researcher will miss something! ${ }^{9}$

\section{References}

1. Robert J. Whitaker, Phys. Teach. 31, 212 (April 1993).

2. Arthur E. Hallerberg, Proceed. Indiana Acad. Sci. 84, 374 (1975).

3. Ibid., pp. 384-386.

4. Ibid., p. 386.

5. Ibid., pp. 383-384. Hallerberg notes that the founding editor of the American Mathematical Monthly, B [enjamin] F[ranklin] Finkel (July 5, 1865-February 5, 1947), taught at "Drury College, Kidder, Missouri." At the time of the founding of the journal, Finkel was affiliated with "Kidder Institute" at Kidder, Missouri from 1892-1895. He moved to Drury College in Springfield, Missouri in 1895 as Professor of Mathematics and Physics (bringing the journal with him); he retired in 1937. See Who Was Who in America, Vol. 2 (The A.N. Marquis Company, Chicago, 1950), p. 186.

6. Arthur E. Hallerberg, Math. Mag. 50, 136 (May 1977).

7. David Singmaster, Math. Intelligencer 7, 69 (1985).

8. Ibid., p. 72.

9. While this note was being written, the following article on this same subject appeared: Steve Groninger, School Sci. Math. 96, 42 (January 1996). 